\title{
A REVIEW ON SISAL, JUTE AND BAMBOO BASED NATURAL FIBERS
}

\begin{tabular}{|l|l|l|}
\hline Amrinder Singh Pannu & Sehijpal Singh & Vikas Dhawan \\
PhD Research Scholar & Professor, & Professor, \\
Mechanical Engineering Department, & Mechanical Engineering Department, & Mechanical Engineering Department, \\
Guru Nanak Dev Engineering College, & Guru Nanak Dev Engineering College, & ITS Engineering College, Greater \\
Ludhiana, Punjab, INDIA & Ludhiana, Punjab, INDIA & Noida, UP, INDIA. \\
Email: erpannu85@gmail.com & Email: $\underline{\text { mech@ gndec.ac.in }}$ & Email: vikas251999@gmail.com \\
\hline
\end{tabular}

\begin{abstract}
Fibers are of two types: natural fiber, which consists of animal and plant fibers, and man-made fiber, which consists of synthetic fibers and regenerated fibers. Natural fibers have been used to reinforce materials for over thousands of years in so many forms. In recent years, natural fibers reinforced composites have received much attention because of their lightweight, nonabrasive, combustible, nontoxic, low cost and biodegradable properties. Many types of natural fibers have been investigated for use in plastics including flax, hemp, jute, sisal and banana. A lot of research work has been performed all over the world on the use of natural fibers as a reinforcing material for the preparation of various types of composites. Unlike carbon and glass fibers, natural fibers are abundantly available from renewable resources. In terms of cost, natural fibers are cheaper than the synthetic alternatives. This paper deals with properties of natural fibers based on bast (jute), leaf (sisal), grass (bamboo) at different conditions. In today's scenario being biodegradable, natural fibers have much importance in environmental friendly composites.
\end{abstract}

Keywords: Natural fibers; civilization; cellulose; environment; bio-degradable

\section{INTRODUCTION}

Natural fibers can be defined as substances produced by plants and animals that can be spun into filament, thread or rope and in a next step be woven, knitted, matted or bound. The oldest fibers used by mankind are flax (10000BC) cotton (5000 BC) and silk (2700 BC), but even jute and coir have been cultivated since antiquity. Because it was one of the first domesticated plants, flax is recognized as a foundation crop of modern civilization.

Natural fiber composites include coir, jute, baggage, cotton, bamboo, hemp. Natural fibers come from plants. These fibers contain lingo cellulose in nature. Natural fibers are eco-friendly; lightweight, strong, renewable, cheap and biodegradable. When determining the properties of natural fibers, one has to keep in mind that one is dealing with natural products with properties that are strongly influenced by their growing environment. Natural fiber composites are attractive to industry because of their low density and ecological advantages over conventional composites. These composites are gaining importance due to their bio-degradable nature Temperature, humidity, the composition of the soil and the air all effect the height of the plant, strength of its fibers, density, etc. Also the way the plants are harvested and processed results in a variation of properties.

\section{CLASSIFICATION}

Natural fibers are classified according to the two factors i.e. plant and animal based. Plant based natural fibers include bast, leaf, fruit, grass, straw, wood pulp and animal based is silk, wool and feathers.

Plants that produce natural fibers are categorized into primary and secondary depending on the utilization. Primary plants are grown for their fibers while secondary plants are plants where the fibers are extracted from the waste product. There are 6 major types of fibers namely; bast fibers, leaf fibers, fruit fibers, grass fibers, straw fibers and other types (wood and roots etc.).

\section{COMPOSITION}

\section{A. Chemical Composition}

Fibers are long strands of molecules interwoven to form a linear, string like structure.They may be natural or made by humans. Among the natural fibers are cellulose, the primary structural component of plants and bacterial cell walls; animal fibers such as wool and silk; and biochemical fibers.

Plant fibers are composed of cellulose, lignin, or similar compounds; animal fibers are composed of protein. Here is the composition of some natural fibers in percentage.

\section{A. Mechanical Composition}

The common factors influencing mechanical properties of natural fibers are experimental conditions, lengths and diameters of individual fibers. Here is the table showing mechanical properties of some common natural fibers 


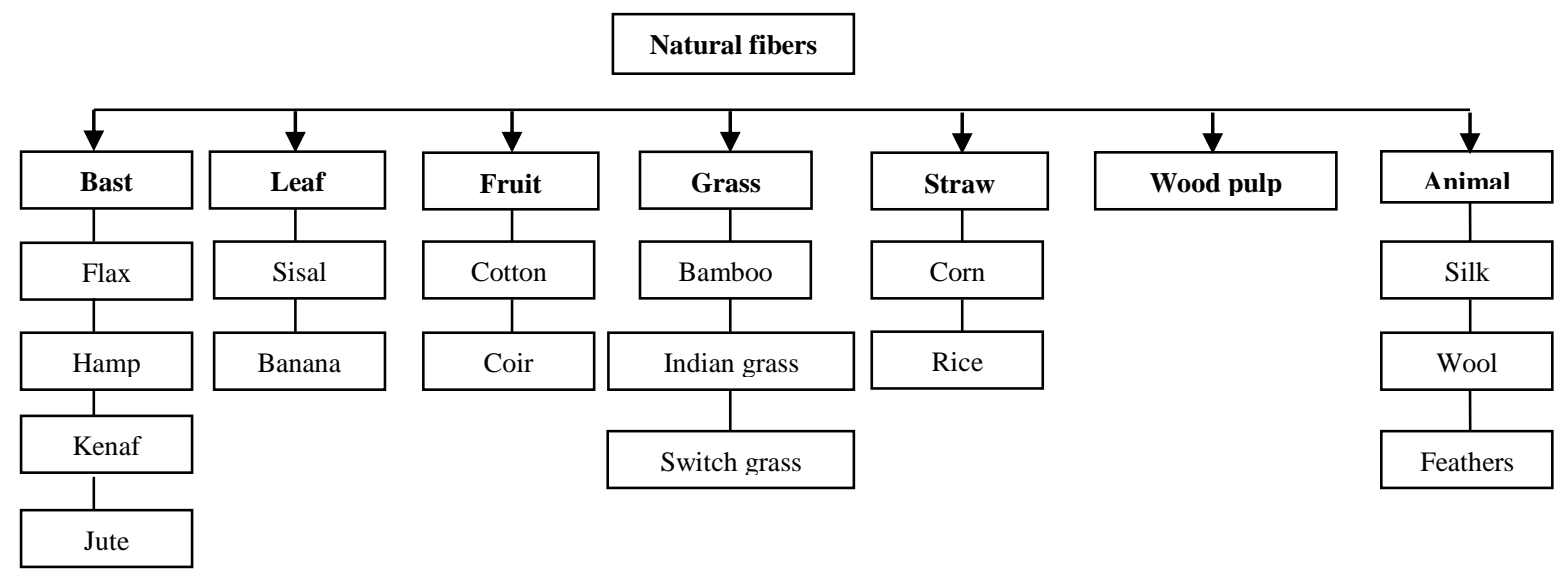

Fig 1: Classification of natural fibers [11]

TABLE NO 1: CHEMICAL AND MECHANICAL COMPOSITION OF NATURAL FIBERS [11,12]

\begin{tabular}{|c|c|c|c|c|c|c|c|c|c|c|c|}
\hline Fiber & $\begin{array}{c}\text { Cellulose } \\
\text { (Wt\%) }\end{array}$ & $\begin{array}{c}\text { Hemicellulose } \\
(\mathrm{Wt} \%)\end{array}$ & $\begin{array}{l}\text { Lignin } \\
(\mathrm{Wt} \%)\end{array}$ & $\begin{array}{l}\text { Pectin } \\
(\mathrm{Wt} \%)\end{array}$ & $\begin{array}{c}\text { Moisture } \\
(\mathrm{Wt} \%)\end{array}$ & Waxes & $\begin{array}{c}\text { Microfibrillar } \\
\text { Angle (Deg) }\end{array}$ & $\begin{array}{l}\text { Densiy } \\
\left(\mathrm{g} / \mathrm{cm}^{2}\right)\end{array}$ & $\begin{array}{c}\text { Tensile } \\
\text { strength } \\
\text { (MPa) }\end{array}$ & $\begin{array}{c}\text { Young } \\
\text { modulus } \\
(\text { GPa })\end{array}$ & $\begin{array}{c}\text { Failure } \\
\text { strain } \\
(\%)\end{array}$ \\
\hline Hemp & 72 & 20.1 & 4.7 & 0.9 & 9 & 0.8 & 2.6 & 1.48 & $350-800$ & $30-60$ & $1.6-4.0$ \\
\hline Sisal & 73 & 12 & 12 & 10 & 16 & 2 & 16 & 1.5 & $300-500$ & $10-30$ & $2-5$ \\
\hline
\end{tabular}

\section{NATURAL FIBER REINFORCEMENT}

\section{A. Sisal fiber}

Sisal fiber is derived from the leaves of the plant. It is usually obtained by machine decortications in which the leaf is crushed between rollers and then mechanically scraped. The fiber is then washed and dried by mechanical or natural means.

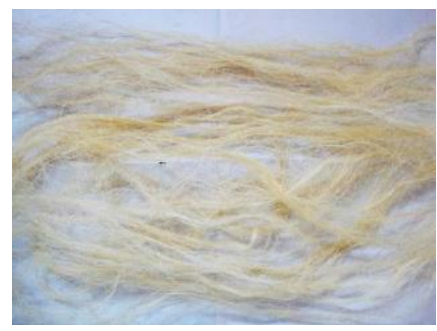

Fig 2: Sisal fibers [13]
The strength of sisal fiber is evaluated by many researchers. The mechanical properties of sisal fibers

obtained from deferent age at three deferent temperatures were investigated [1]. The tensile strength, modulus and toughness values of sisal fiber decrease with increasing temperature. Chand et al. [2] reported the effects of testing speed and gauge length on the mechanical properties of other kinds of natural fibers. When the gauge length is $50 \mathrm{~mm}$ and testing speed is $50 \mathrm{~mm} / \mathrm{min}$, the tensile strength of sisal fiber is $759 \mathrm{MPa}$. However, for sun-hemp fiber, the tensile strength is only $283 \mathrm{MPa}$.

Yang et al. [3] studied the relationship of surface modication and tensile properties of sisal fibers. Their modification methods include: alkali treatment, $\mathrm{H} 2 \mathrm{SO} 4$ treatment, conjoint $\mathrm{H} 2 \mathrm{SO} 4$ and alkali treatment, benzol/ alcohol dewax treatment, acetylated treatment, thermal treatment, alkali-thermal treatment and thermal-alkali treatment. Maximum tensile strength is with thermal treatment i.e. $42 \mathrm{~g} / \mathrm{tex}$, tensile modulus is $1.22 \times 10^{3} \mathrm{~g} / \mathrm{tex}$ 


\section{Asia Pacific Journals}

and elongation at break is $3.5 \%$. Maximum elongation of $8.3 \%$ is with Acetylated treatment. All the results of treatments are shown in table no 2: from which we can evaluate the better treatment for the required property of the sisal fibers.

TABLE NO 2: EFFECT OF TREATMENT METHODS ON TENSILE PROPERTIES OF SISAL FIBERS [3]

\begin{tabular}{|l|c|c|c|}
\hline $\begin{array}{c}\text { Treatment } \\
\text { methods }\end{array}$ & $\begin{array}{c}\text { Tensile } \\
\text { strength } \\
(\mathbf{g} / \text { tex })\end{array}$ & $\begin{array}{c}\text { Tensile } \\
\text { modulus } \\
\left(\mathbf{x 1 0}^{\mathbf{3}} \mathbf{g} / \mathbf{t e x}\right)\end{array}$ & $\begin{array}{c}\text { Elongation at } \\
\text { break (\%) }\end{array}$ \\
\hline Untreated & 30.7 & 1.18 & 2.5 \\
\hline Benzol/alcohol & 38.8 & 0.99 & 3.7 \\
\hline Acetic acid+alkali & 9.3 & 0.39 & 2.6 \\
\hline Alkali & 31.7 & 0.53 & 7.5 \\
\hline Acetylated & 33.2 & 0.35 & 8.3 \\
\hline Thermal & 42.0 & 1.22 & 3.5 \\
\hline Alkali-thermal & 27.6 & 0.70 & 4.7 \\
\hline Thermal-alkali & 25.7 & 0.71 & 4.4 \\
\hline
\end{tabular}

\section{B. Jute fiber}

Jute is a long, soft, shiny vegetable fiber that can be spun into coarse, strong threads. Out of some investigations, Khan et.al [4] fabricated the composite by using short jute fiber of length 2 - $3 \mathrm{~mm}$ with polypropylene as resin.

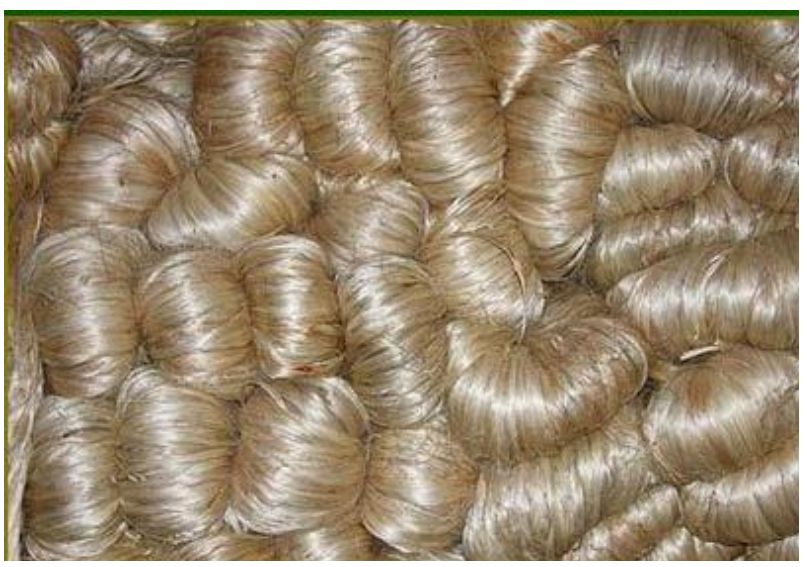

Fig 3: Jute fibers [12]

The composites were prepared considering fiber by weight $20 \%$ and resin by weight $80 \%$ using compression molding. The mechanical properties were evaluated such as flexural strength, tensile strength, impact strength, and tensile modulus, elongation at break, flexural modulus and hardness of the composites [4].

The significant reduction in flexural strength is due to the impact induced damage and that the residual flexural
ISBN: 978-81-930411-4-7

strength is more susceptible to damage than residual flexural modulus.

A number of studies are available on the impact behaviour of unidirectional laminated composites [5]. The improvement in the jute vinlyl ester composite by treating jute fiber with $\mathrm{NaOH}(5 \%)$ solution for $0,2,4,6$ and 8 hours at $30^{\circ} \mathrm{C}$ was evaluated.

Jute fiber reinforced at 35 weight percentage and treated for 4 hours showed an improvement in the flexural strength by $20 \%$, for the flexural modulus $23 \%$, and $18 \%$ for the laminar shear strength [6]. Impact of load on dispacmenet of the jute reinforced composites with treated and untreated fibers is shown in figure 4 from where we can establish the correlation between the treatments of jute fibers.

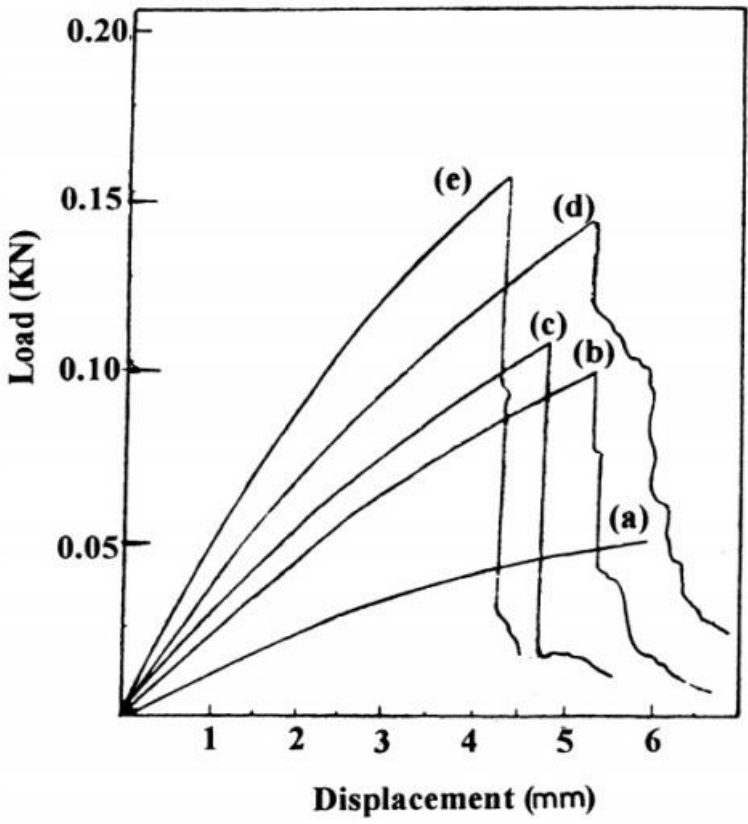

Fig 4: Load-displacement curves of jute reinforced composites: (a) vinylester resin; 23 wt\% fibers, (b) untreated, (c) $4 \mathrm{~h} \mathrm{NaOH}$ treated; 35 wt $\%$ fibers, (d) untreated and (e) $4 \mathrm{~h} \mathrm{NaOH}$ treated. [6] 
TABLE NO 3: TENSILE AND FLEXURAL PROPERTIES OF POLYPROPYLENE SHEET AND THE COMPOSITES (20\% FIBER BY WEIGHT). [4]

\begin{tabular}{|c|c|c|c|c|c|}
\hline \multirow{2}{*}{ Material } & \multicolumn{4}{|c|}{ Tensile and flexural properties } \\
\cline { 2 - 6 } & \multicolumn{3}{|c|}{ Tensile properties } & \multicolumn{3}{c|}{ Flexural properties } \\
\cline { 2 - 6 } & Strength (MPa) & Modulus (MPa) & $\begin{array}{c}\text { Elongation at } \\
\text { break (\%) }\end{array}$ & Strength (MPa) & Modulus (MPa) \\
\hline Polypropylene & $21 \pm 0.8$ & $640 \pm 14$ & $340 \pm 30$ & $28 \pm 1.2$ & $1040 \pm 30$ \\
\hline $\begin{array}{c}\text { Short Jute Fiber/PP } \\
\text { Composite }\end{array}$ & $32 \pm 0.3$ & $850 \pm 10$ & $12 \pm 2$ & $38 \pm 0.3$ & $1685 \pm 23$ \\
\hline $\begin{array}{c}\text { Short E-glass } \\
\text { Fiber/PP Composite }\end{array}$ & $31 \pm 0.4$ & $790 \pm 15$ & $38 \pm 3$ & $36 \pm 0.8$ & $1265 \pm 20$ \\
\hline
\end{tabular}

Bijwe [7] in case of aramid fabric/polyethersulfone composites. The bidirectional jute fiber composite can bear higher load before failure compared to neat or unfilled epoxy. The tensile strength varies from $43 \mathrm{MPa}$ to $110 \mathrm{MPa}$ and tensile modulus from $0.15 \mathrm{GPa}$ to 4.45 $\mathrm{GPa}$ with the fiber varies from 0 to $48 \mathrm{wt} \%$. The flexural strength and modulus of the composites increases with the increase in the fiber loading after 12 wt. \% fiber loading. The maximum flexural strength and modulus of $55.8 \mathrm{MPa}$ and $3.02 \mathrm{GPa}$ respectively, is obtained at $48 \mathrm{wt}$. \% of fiber loading. The flexural strength and modulus of $48 \mathrm{wt}$. $\%$ fiber loading are increased by $20 \%$ and $37 \%$ in comparison to the neat epoxy. The jute fiber inclusions enhance the load bearing capacity and ability to withstand bending of the composites [8]. Jute fiber reinforced epoxy composites were analyzed with effect of fiber orientation. The fiber orientations were $0 / 90^{\circ}, 15^{\circ} /-75^{\circ}, 30^{\circ} /-60^{\circ}$ and $45^{\circ} / 45^{\circ}$. The higher strength and stiffness were found at $0 / 90^{\circ}$ fiber orientation. Compressive test of jute composite were tested and it found higher strength as compared to bamboo fiber reinforced epoxy composites [9]. The alkali treated jute fiber reinforced epoxy composites showed improved mechanical properties. The improvement was maximum for the composite prepared with 4 hrs alkali treated jute fibers [10].

\section{Bamboo fiber}

The bamboo fiber is made from the starchy pulp of bamboo plants. This textile fiber is fabricated from natural bamboo and other additives. In fact, bamboo fiber is a regenerated cellulose fiber, which is produced from bamboo pulp, processed from bamboo culms.

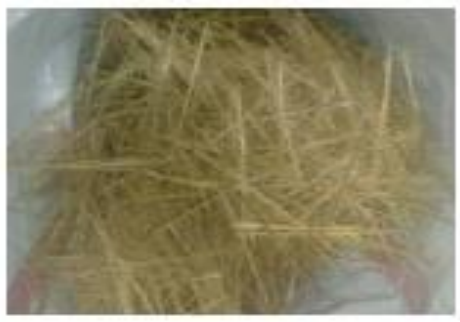

Fig 5: Bamboo fibers [19]
In the process of embedding bamboo fibers in resin, the bamboo strips are moulded and pressed under the certain pressure. Kushwaha and Kumar [14] used bamboo strips mat to reinforced epoxy and unsaturated polyester materials. The prepared composites were cured in oven at $80^{\circ} \mathrm{C}$ for 4 and a half hour. As compared the treated to untreated bamboo fiber composite, the elastic modulus of treated bamboo fiber composite increased. Yang et al. [15] adjusted phenolic resin to bamboo fiber bundles at room temperature.

The glued specimen were pressed with a cold press machine in a mould under $82 \mathrm{MPa}$ pressure and then cured in an oven. In contrast with raw bamboo fiber and other bamboo based composites, both tensile and compression strength of bamboo fiber composite were increased.

Recently, the utilization of bamboo fibers as reinforced polymer composite material has been increased by advanced processing technology. Table 4 displays the advantages of bamboo fibers over glass fiber which is one of the most common polymer materials.

TABLE 4: COMPARISON OF BAMBOO AND GLASS FIBER [16], [17], [18]

\begin{tabular}{|c|c|c|}
\hline Properties & Bamboo & Glass \\
\hline Density & Low & Higher than bamboo fiber \\
\hline Cost & Low & Higher than bamboo fiber \\
\hline Disposal & Biodegradable & Non-biodegradable \\
\hline CO2 Absorption & Yes & No \\
\hline Recyclability & Yes & No \\
\hline Renewability & Yes & No \\
\hline Energy for extraction & Low & High \\
\hline
\end{tabular}

D. CONCLUSION

Natural fibers are very good and demanding alternatives to synthetic fibers as they are decomposable and doesn't produce any harm to the environment with any type of toxic emissions. From the review of jute and sisal fiber it has been concluded that sisal fiber's mechanical properties diminished at higher temperatures and with 


\section{ELK Asia Pacific Journals - Special Issue \\ ISBN: 978-81-930411-4-7}

Epoxy Composites Reinforced with SiC Derived from Rice Husk", 29(18), p. 2869, 2010

[9] Patel "Environmental effect of water absorption and flexural strength of red mud filled jute fiber/polymer composite", International journal of Engineering, Science and Technology, Vol.4 (4), 49-59, 2012

[10] Siddiquee "Investigation of an optimum method of Biodegradation process for jute polymer composites", American Journal of Engineering Research, Vol.3 (1), 200-206, 2014

[11] C. W. Nguong, S. N. B. Lee, and D. Sujan, "A Review on Natural Fiber Reinforced Polymer Composites" World Academy of Science, Engineering and Technology International Journal of Chemical, Nuclear, Materials and Metallurgical Engineering Vol:7, No:1, 2013

[12] U.S.Bongarde , V.D.Shinde, "Review on natural fiber reinforcement polymer composites" International Journal of Engineering Science and Innovative Technology (IJESIT) Volume 3, Issue 2, 2014

[13] Dr. K R Dinesh, Jagadish $\mathrm{S} \quad \mathrm{P}$, Dr. A Thimmanagouda, Dr. Neeta Hatapaki, "Characterization and Investigation of Tensile and Compression Test on Sisal Fiber Reinforcement Epoxy Composite Materials used as Orthopaedic Implant", International Journal of Application or Innovation in Engineering \& Management (IJAIEM), Volume 2, Issue 12, 2013

[14] P. K. Kushwaha and R. Kumar, "Studies on Performance of Acrylonitrile-Pretreated BambooReinforced Thermosetting Resin Composites," Journal of Reinforced Plastics and Composites, vol. 29, pp. 13471352, 2010.

[15] Y. L. Yu, X. A. Huang, and W. J. Yu, "High performance of bamboo-based fiber composites from long bamboo fiber bundles and phenolic resins," Journal of Applied Polymer Science, 2014.

[16] N. T. Phong, T. Fujii, B. Chuong, and K. Okubo, "Study on How to Effectively Extract Bamboo Fibers from Raw Bamboo and Wastewater Treatment," Journal of Materials Science Research, vol. 1, 2012.

[17] P. K. Kushwaha and R. Kumar, "Studies on Performance of Acrylonitrile-Pretreated BambooReinforced Thermosetting Resin Composites," Journal of Reinforced Plastics and Composites, vol. 29, pp. 13471352, 2010. 
[18] O. L. Trujillo EE, Fuentes C, Van Vuure A and Verpoest I., "Bamboo fiber thermoplastic for transport applications," presented at the International Technical Conferences and Forum, Paris, 2010.

[19] Kannan Rassiah and M.M. H Megat Ahmad, "A Review On Mechanical Properties Of Bamboo Fiber Reinforced Polymer Composite", Australian Journal of Basic and Applied Sciences, 7(8): 247-253, 2013 